\title{
Erosion of forestry land: causes and rehabilitation
}

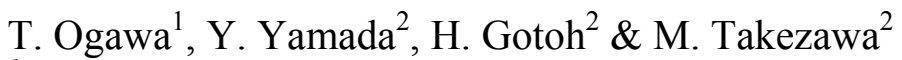 \\ ${ }^{1}$ Forest Survey Office, Japan \\ ${ }^{2}$ Department of Civil Engineering, College of Science \& Technology, \\ Nihon University, Japan
}

\begin{abstract}
Forests cover $70 \%$ of the total land area of Japan. Forest lands within Japan are prone to landslides because weakly resistant geological units are eroded by water flowing down steep slopes that are subjected to annual rainfall amounts that are 2.5-times the global average. The environmental effects of deforestation impact upon atmospheric pollution, wildlife, the hydrological cycle, water resources, soil erosion, and the occurrence of landslides. To mitigate disasters that occur upon forestry land, it is important to forecast landslide development and plan for the provision of remedial measures during disaster rehabilitation. This paper describes the causes of the erosion of forestry land and methods of disaster rehabilitation via a case study of the upper reaches of the Tama River, Japan, which is a national park and an important water resource for the Tokyo Metropolitan area. The causes of erosion of forestry land within the upper reaches of the Tama River are classified as one of the following: shallow landslides related to the loss of under-story vegetation, collapse of steep slopes, damage related to the consumption of vegetation by wildlife, and debris flows that occur during periods of torrential rain. In recent times, heavy rains over eroded forestry land within the upper reaches of the Tama River have produced muddy river water due to the erosion and degradation of mountain slopes. In addition, grazing by Japanese deer has destroyed many trees within the upper reaches of the Tama River, and the torrent bed within this area, previously planted with Japanese horseradish, was lost during a debris flow. In this paper, we describe anti-erosion measures undertaken for disaster rehabilitation of wasted forestry land, including timber-thinning methods and the control of wildlife numbers.
\end{abstract}

Keywords: erosion of forestry land, deforestation, disaster rehabilitation, landslide. 


\section{Introduction}

It is fair to say that a human life is created by the green of the forest that brings about a mild climate, saves a water resource, and serves the coexistence of animals and plants. The forest is a stable system that can sustain nature. About $70 \%$ of the total land area of Japan is forested. Japan is blessed with the most abundant forest resources of any country in the world. The forests of Japan were depleted during the Second World War, but Japanese red cedar (Cryptomeria japonica) and Hinoki cypress (Chamaecyparis obtuse) were replanted during the post-war period at the demand of the Japanese Government. Plantation forests currently comprise about $40 \%$ of the total forests in Japan, but such wood is in poor demand because foreign lumber can get purchased cheaply. The cost of a $\log$ of Japanese red cedar or Hinoki cypress is just $33 \%$ or less of the price 25 years ago. The rate of self-sufficiency of forests in Japan is less than $20 \%$; consequently, the average age of forestry workers increases and the next generation of forestry owners have moved to the city because forestry is not a desirable career. Hence, the management of forests in Japan has been neglected in recent times, leading to erosion and poor water conservation. In this paper, we discuss the causes of eroded forest land and possible rehabilitation measures.

\section{Forest land in Japan}

The forested area of Japan has decreased with increasing population and the development of agricultural fields. The cultivated acreage of forest was about 8.62 million ha for about 7,000,000 people in $930 \mathrm{AD}$, increasing to 54 million ha for 121,000,000 people in 1990: an increase in persons per 1 ha of cultivated acreage from 8.1 to 22.4 . Temporal trends in population and cultivated acreage are shown in Table 1 (Iketani [1]).

Table 1: $\quad$ Temporal trends in cultivated acreage and population within Japan.

\begin{tabular}{|c|c|c|c|}
\hline Year & $\begin{array}{c}\text { Cultivated acreage } \\
\text { (million ha) }\end{array}$ & $\begin{array}{c}\text { Population } \\
\text { (million) }\end{array}$ & Persons per hectare \\
\hline 930 & 8.62 & 7 & 8.1 \\
\hline 1450 & 9.46 & 10 & 10.5 \\
\hline 1600 & 16.35 & 19.6 & 12.0 \\
\hline 1720 & 29.70 & 31 & 10.4 \\
\hline 1874 & 30.50 & 34 & 11.1 \\
\hline 1990 & 54.00 & 121 & 22.4 \\
\hline
\end{tabular}

The sizes of areas of protected forest in Japan in 2004 are shown in Table 2. The 'Other' category in the table includes shifting-sand prevention forest, windbreak forest, flood-damage prevention forest, tidal wave and salty wind prevention forest, drought-prevention forest, snow-drift prevention forest, foginflow prevention forest, snow-avalanche prevention forest, rock-fall prevention forest, fire protection forest, fish-breeding forest, navigation landmark forest, 
public health forest, and scenic-site conservation forest. Headwater conservation forest comprises $68.4 \%$ of protected forest, while soil run-off prevention forest comprises $21.5 \%$, as shown in Table 2 (JFS [2]).

Table 2: $\quad$ Land areas of different types of protected forest.

\begin{tabular}{|l|c|c|r|r|}
\hline Classification & National forest & Non-national forest & Total & Ration \\
\hline $\begin{array}{l}\text { Headwater } \\
\text { conservation } \\
\text { forest }\end{array}$ & 4,228 & 3,216 & 7,444 & $68.4 \%$ \\
\hline $\begin{array}{l}\text { Soil run off } \\
\text { prevention } \\
\text { forest }\end{array}$ & 935 & 1,404 & 2,399 & $21.5 \%$ \\
\hline $\begin{array}{l}\text { Landslide } \\
\text { prevention } \\
\text { forest }\end{array}$ & 19 & 37 & 56 & $0.5 \%$ \\
\hline Other & 458 & 590 & 1,048 & $9.6 \%$ \\
\hline
\end{tabular}

(unit: thousand ha).

Felled forestry land was 19,830 ha; the total area of landslides per 100 ha was $2.38 \mathrm{ha}$; and the total area of landslides in areas of mature forest (190,328 ha) was 1.17 ha per 100 ha. Differences in landslide development between areas of mature forest and felled areas are shown in Table 3 (JSECE [3]). The total landslide area per 100 ha of felled land is about 2-times that of mature forest areas, as shown in Table 3. Therefore, one of the causes of landslide development is deforestation.

Table 3: $\quad$ Relations between areas of felled forest and landslide development.

\begin{tabular}{|l|c|c|c|c|}
\hline Kind & $\begin{array}{c}\text { Area } \\
\text { (ha) }\end{array}$ & $\begin{array}{l}\text { Landslide } \\
\text { (places) }\end{array}$ & $\begin{array}{c}\text { Landslide } \\
\text { (ha) }\end{array}$ & $\begin{array}{l}\text { Landslide } \\
\text { area } \\
\text { (100 ha) }\end{array}$ \\
\hline Tree-grown area & 190,328 & 11,286 & 2,277 & 1.17 \\
\hline Cut-over land & 19,830 & 2,377 & 398 & 2.38 \\
\hline Total & 210,158 & 13,663 & 2,625 & 1.25 \\
\hline
\end{tabular}

Trees and plants in general affect the hydrological cycle in a number of significant ways. Therefore, the presence or absence of trees can change the quantity of water upon the land surface, within the soil or groundwater reservoir, and in the atmosphere. Deforestation generally increases the rate of soil erosion by increasing the amount of runoff and reducing the protection of the soil afforded by tree litter. Forestry operations themselves also increase erosion via the development of roads and the use of mechanized equipment. A further cause of landslide development is the grazing of wild animals. In some cases, treeless hills result from the grazing upon growing herbage of wild animals such as deer, monkey, and bear. The surface of the earth is then exposed and washed away during rainfall. Tree roots act to bind soil between the roots and between the 
roots and underlying bedrock if the soil is sufficiently shallow. The risk of landslides is therefore increased when trees are removed from steep slopes with shallow soil and when subjected to the grazing of wild animals. The following case study provides an example of the way in which the rehabilitation of eroded forest land is planned and executed in Japan.

\section{Case study}

The rehabilitation of eroded forest land is planned for the area around the Sakasa River, a branch of the Tama River, as shown in Figure 1 (JT [4]). The study area of the current investigation comprises 131 ha of fast-moving river and hillsides within the 220-ha basin catchment of the Sakasa River. The Sakasa Basin contains 198.07 ha of forest that is designated a protected area with the status of 'protection for headwater conservation'.

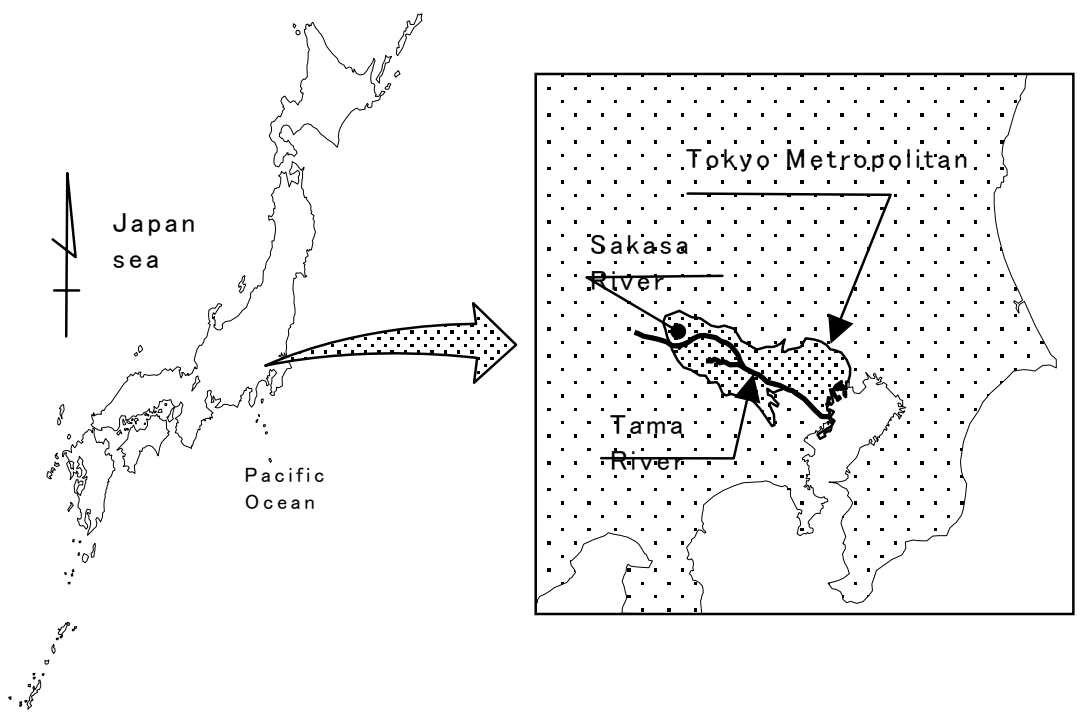

Figure 1: Location map of the study area.

The study area is the mountainous region between Kawanori Mountain, with an altitude of $1353 \mathrm{~m}$, and Honnita Mountain, with an altitude of $2245 \mathrm{~m}$. The upper reaches of the Sakasa River flow to the south, while the middle reaches flow to the west following a $90^{\circ}$ change in flow direction at an altitude of $790 \mathrm{~m}$ related to a geological rift. The topography of the upper Sakasa River formed from crustal movements, and large-scale landslides occur at 3 sites in the upper river. Hillsides in this area are steep, with an average slope of $36^{\circ}$. Eroded subvertical cliffs occur at the levee foot of mountain streams in particular, and the slopes of the lower parts of such cliffs are in excess of $60^{\circ}$. The bed slope of the Kawanori River where it joins the Sakasa River is $10^{\circ}$; this section of the river forms a V-shaped valley with numerous falls of 50-60 m. The average 
slope of the riverbed of the upper Sakasa River is $16^{\circ}$; this section of river contains many falls of 2-10 m, and rocks are exposed along the majority of the rivercourse. There are three main river branches within the Sakasa Basin. Most areas within the river basins are $20-45$ ha in size and many bed slopes are in excess of $20^{\circ}$.

The topography of the Sakasa River consists of six distinct regions, as shown in Table 4 and Figure 2.

Table 4: Characteristics of the topography of the Sakasa River.

\begin{tabular}{|c|c|c|l|c|c|c|}
\hline Part & $\begin{array}{l}\text { Area } \\
(\mathrm{ha})\end{array}$ & $\begin{array}{l}\text { Length } \\
(\mathrm{m})\end{array}$ & $\begin{array}{l}\text { Height } \\
\text { ratio }\end{array}$ & $\begin{array}{l}\text { Bed } \\
\text { slope } \\
(\%)\end{array}$ & $\begin{array}{l}\text { Slope } \\
\text { angle } \\
(\mathrm{Deg})\end{array}$ & $\begin{array}{l}\text { Elonga- } \\
\text { tion ratio }\end{array}$ \\
\hline Lower & 35.85 & 720 & 160 & 22 & 41 & \\
\hline Midstream & 10.63 & 540 & 90 & 17 & 38 & \\
\hline Upper & 85.64 & 1390 & 460 & 33 & 35 & 0.75 \\
\hline 1 stream & 19.84 & 570 & 290 & 51 & 38 & 0.88 \\
\hline 2 stream & 22.72 & 630 & 330 & 52 & 37 & 0.85 \\
\hline 3 stream & 45.32 & 900 & 360 & 40 & 35 & 0.84 \\
\hline Total & 220.00 & 2650 & 710 & 28 & 37 & 0.63 \\
\hline
\end{tabular}

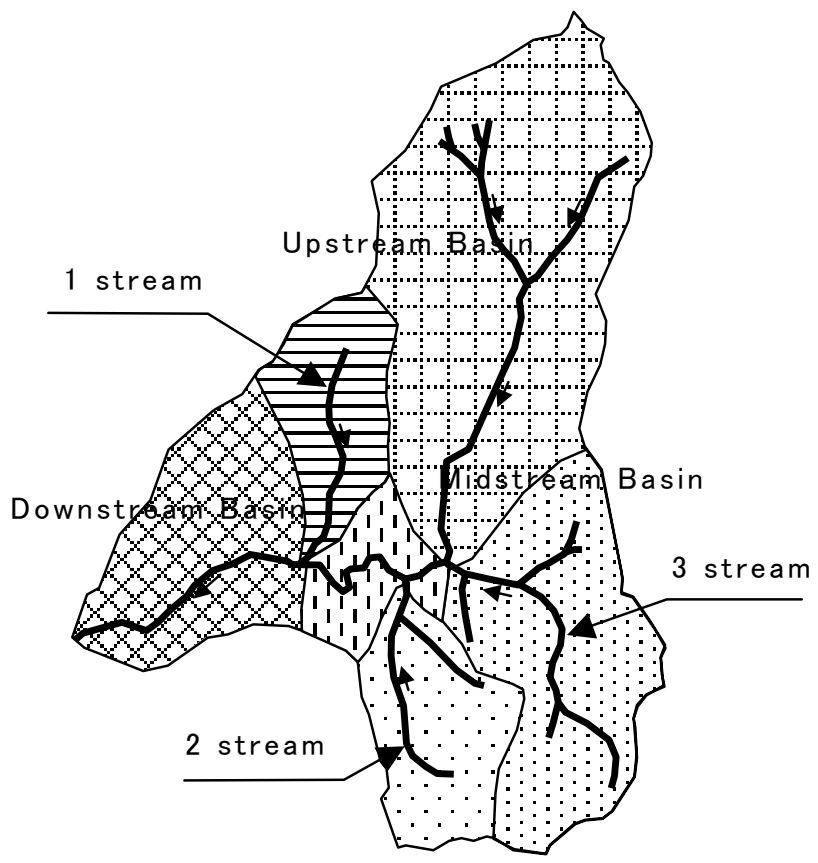

Figure 2: Six-part topographic division of the Sakasa River catchment. 
The elongation ratio $(E)$ is given by the equation $E=(2 / L) \sqrt{ }(A / \pi)$, where $L$ is the river length $(\mathrm{m}), \mathrm{A}$ is area (ha), and $\pi$ is the circular constant. The geology of the study area consists of Late Jurassic sandstone underlain by Middle Jurassic shale. The sandstone and shale is overlain by a layer of loam in mountainous areas; the loam is weak and commonly deformed.

Temperature and precipitation data for altitudes of $550 \mathrm{~m}, 1000 \mathrm{~m}$, and 1363 $\mathrm{m}$ are shown in Table 5 . The maximum recorded rates of rainfall are $71 \mathrm{~mm} /$ hour (1991/8/20), $347 \mathrm{~mm} /$ day (2001/9/10), and $634 \mathrm{~mm} / 3$ days (2001/9/10).

Cryptomeria japonica and Chamaecyparis obtuse planted over the past 30-50 years now covers about $60 \%$ of the total forest area across the study site. A classification of the forest area on the basis of tree type is shown in Table 6, while eroded forest land is classified in terms of three types of eroded hillsides and torrent-erosion, as shown in Table 7. Eroded forest land is classified in terms of rainfall, intensity of felling, and damage related to grazing by Japanese deer. In recent years, Japan has been struck by severe typhoons and torrential rain, such that the amount of eroded forest land has increased due to a combination of these rainfall conditions, weak soil, and the grazing of Japanese deer. The main cause of erosion of forest land in the study area is grazing by increasing numbers of Japanese deer that eat the buds and roots of trees. Rehabilitation of the eroded forest land requires the control and management of an appropriate population of Japanese deer. Measures to prevent run-off include hillside works such as the conservation of vegetation within devastated lands and torrent works such as the protection of valleys that contain unstable soil.

Table 5: $\quad$ Temperature and precipitation data for different altitudes.

\begin{tabular}{|c|c|c|c|}
\hline & Altitude $530 \mathrm{~m}$ & $\begin{array}{c}\text { Altitude } 1000 \\
\mathrm{~m}\end{array}$ & $\begin{array}{c}\text { Altitude } 1363 \\
\mathrm{~m}\end{array}$ \\
\hline Average temperature & $11.8^{0} \mathrm{C}$ & $9.0^{0} \mathrm{C}$ & $6.8^{0} \mathrm{C}$ \\
\hline $\begin{array}{c}\text { Volume of } \\
\text { temperature } \\
\text { Warming }\end{array}$ & 90.1 & 67.7 & 51.6 \\
\hline $\begin{array}{c}\text { Volume of } \\
\text { temperature } \\
\text { Coldness }\end{array}$ & -8.5 & -19.7 & -30.0 \\
\hline $\begin{array}{c}\text { Classification of } \\
\text { forest zone }\end{array}$ & $\begin{array}{c}\text { Temperate } \\
\text { zone, evergreen } \\
\text { and broadleaf } \\
\text { forest }\end{array}$ & $\begin{array}{c}\text { Temperate zone } \\
\text { and fallen leaf } \\
\text { forest }\end{array}$ & $\begin{array}{c}\text { Cold zone and } \\
\text { fallen leaf } \\
\text { forest }\end{array}$ \\
\hline Annual precipitation & $1595 \mathrm{~mm}$ & $1971 \mathrm{~mm}$ & $2259 \mathrm{~mm}$ \\
\hline
\end{tabular}

Table 8 describes the characteristics of different types of hillside and torrent works in terms of: (1) type of works, (2) effectiveness, (3) durability, (4) value for money, (5) ease of undertaking the work, (6) ease of transportation of materials, (7) protection of the landscape, (8) combats grazing by Japanese deer, 
and (9) overall evaluation. The meanings of the symbols used in the figure are as follows: (O): very good performance; $\mathrm{O}$ : good performance; $\triangle$ : poor performance; and $X$ : very poor performance. Hillside work is classified as either technical hillside work or hillside-seeding work. Table 8 (a) assesses soilretaining works as part of technical hillside works. Basket-retaining works (A) perform well in both sides of the water-channel work, while log-piling work (C) performs well in soil-retaining works Table 8 (b) assesses water-channel work as part of technical hillside work; the wire net shows the best performance.

Table 6: Classification of forest areas on the basis of tree type.

\begin{tabular}{|l|c|}
\hline \multicolumn{1}{|c|}{ Kind of tree } & Area \\
\hline Cryptomeria japonica and Chamaecyparis obtuse & $60.63 \mathrm{ha} \mathrm{(27 \% )}$ \\
\hline Cryptomeria japonica & $28.45 \mathrm{ha} \mathrm{(13 \% )}$ \\
\hline Chamaecyparis obtuse and Broad leaved trees & $33.70 \mathrm{ha} \mathrm{(15 \% )}$ \\
\hline Chamaecyparis obtuse & $3.30 \mathrm{ha} \mathrm{(2 \% )}$ \\
\hline $\begin{array}{l}\text { Quercus mongolica var. grosseserrata and Broad } \\
\text { leaved trees }\end{array}$ & $49.80 \mathrm{ha} \mathrm{(23 \% )}$ \\
\hline $\begin{array}{l}\text { Quercus mongolica var. grossesrrata and Larix } \\
\text { leptolepis }\end{array}$ & $3.75 \mathrm{ha} \mathrm{(2 \% )}$ \\
\hline Quercus mongolica var. grossesrrata & $5.57 \mathrm{ha} \mathrm{(3 \% )}$ \\
\hline Quercus serrata and Broad leaves trees & $16.05 \mathrm{ha} \mathrm{(7 \% )}$ \\
\hline Others broad leaves trees & $12.05 \mathrm{ha} \mathrm{(5 \% )}$ \\
\hline Tsuga sieboldii & $4.10 \mathrm{ha} \mathrm{(2 \% )}$ \\
\hline Pinus densiflora & $0.80 \mathrm{ha} \mathrm{(0 \% )}$ \\
\hline Larix leptolepis & $1.80 \mathrm{ha} \mathrm{(1 \% )}$ \\
\hline Total & $220.00 \mathrm{ha} \mathrm{(100 \% )}$ \\
\hline
\end{tabular}

Table 7: $\quad$ Classification scheme of eroded forest land.

\begin{tabular}{|l|l|}
\hline \multicolumn{1}{|c|}{ Classification } & \multicolumn{1}{|c|}{ Form } \\
\hline Eroded hillside (1) & $\begin{array}{l}\text { Outflow of surface soil by loss of under-story } \\
\text { vegetation }\end{array}$ \\
\hline Eroded hillside (2) & Slope failure of steep slope \\
\hline Eroded hillside (3) & Harm of deer's food \\
\hline Eroded torrent & Outflow zone of soil by torrent bed gradient \\
\hline
\end{tabular}

Table 8 (c) provides an assessment of different wattle fence and linear sodding works as part of hillside seeding works. Log wattle fences and log linear sodding provide good performance because thinning lumber can be used.

Table 8 (d) provides an assessment of covering works as part of hillside seeding works. In this case, natural fiber mat provides the best performance.

Table 8 (e) provides an assessment of covering works to protect vegetation from grazing by Japanese deer. Combined works involving a thick layer wire net and SHIKATTO works provides the best results, where the SHIKATTO work provides protection from grazing by deer. 
Table 8: (a) Technical hillside works (soil-retaining works); (b) Technical hillside works (water-channel works); (c) Hillside seeding works (wattle fence and linear sodding works); (d) Hillside seeding works (covering works); (e) Hillside seeding works (covering works: ward off Japanese deer); (f) Torrent works.

(a)

\begin{tabular}{|l|l|l|l|l|l|l|l|l|}
\hline$(1)$ & $(2)$ & $(3)$ & $(4)$ & $(5)$ & $(6)$ & $(7)$ & $(8)$ & $(9)$ \\
\hline $\mathrm{A}$ & $\bigcirc$ & $\bigcirc$ & $\bigcirc$ & $\bigcirc$ & $\bigcirc$ & $\bigcirc$ & - & $\bigcirc$ \\
\hline $\mathrm{B}$ & $\bigcirc$ & $\bigcirc$ & $\bigcirc$ & $\triangle$ & $\triangle$ & $\triangle$ & - & $\triangle$ \\
\hline $\mathrm{C}$ & $\bigcirc$ & $\triangle$ & $\triangle$ & $\bigcirc$ & $\bigcirc$ & $\bigcirc$ & - & $\bigcirc$ \\
\hline $\mathrm{D}$ & $\bigcirc$ & $\triangle$ & $\bigcirc$ & $\bigcirc$ & $\bigcirc$ & $\bigcirc$ & - & $\bigcirc$ \\
\hline
\end{tabular}

A: Basket retain work, B: Wire basket work, C: Log piling work, D: Wood steel wall.

(b)

\begin{tabular}{|l|l|l|l|l|l|l|l|l|}
\hline$(1)$ & $(2)$ & $(3)$ & $(4)$ & $(5)$ & $(6)$ & $(7)$ & $(8)$ & $(9)$ \\
\hline $\mathrm{E}$ & $\bigcirc$ & $\bigcirc$ & $\bigcirc$ & $\triangle$ & $\bigcirc$ & $\bigcirc$ & $\bigcirc$ & $\bigcirc$ \\
\hline $\mathrm{F}$ & $\bigcirc$ & $\bigcirc$ & $\bigcirc$ & $\bigcirc$ & $\bigcirc$ & $\bigcirc$ & $\bigcirc$ & $\bigcirc$ \\
\hline $\mathrm{G}$ & $\bigcirc$ & $\bigcirc$ & $\triangle$ & $\triangle$ & $\triangle$ & $\bigcirc$ & $\times$ & $\triangle$ \\
\hline $\mathrm{H}$ & $\bigcirc$ & $\bigcirc$ & $\triangle$ & $\triangle$ & $\triangle$ & $\triangle$ & $\bigcirc$ & $\triangle$ \\
\hline
\end{tabular}

E: Sand bag, F: Wire net, G: Sodded channel, H: Corrugated metal pipe.

(c)

\begin{tabular}{|l|l|l|l|l|l|l|l|l|}
\hline$(1)$ & $(2)$ & $(3)$ & $(4)$ & $(5)$ & $(6)$ & $(7)$ & $(8)$ & $(9)$ \\
\hline $\mathrm{I}$ & $\bigcirc$ & $\triangle$ & $\bigcirc$ & $\triangle$ & $\triangle$ & $\bigcirc$ & $\bigcirc$ & $\triangle$ \\
\hline $\mathrm{J}$ & $\bigcirc$ & $\triangle$ & $\bigcirc$ & $\bigcirc$ & $\bigcirc$ & $\bigcirc$ & $\bigcirc$ & $\bigcirc$ \\
\hline $\mathrm{K}$ & $\bigcirc$ & $\bigcirc$ & $\bigcirc$ & $\bigcirc$ & $\bigcirc$ & $\bigcirc$ & $\bigcirc$ & $\bigcirc$ \\
\hline $\mathrm{L}$ & $\bigcirc$ & $\bigcirc$ & $\bigcirc$ & $\bigcirc$ & $\bigcirc$ & $\triangle$ & $\bigcirc$ & $\bigcirc$ \\
\hline $\mathrm{M}$ & $\bigcirc$ & $\triangle$ & $\bigcirc$ & $\bigcirc$ & $\bigcirc$ & $\bigcirc$ & $\bigcirc$ & $\bigcirc$ \\
\hline $\mathrm{N}$ & $\bigcirc$ & $\triangle$ & $\bigcirc$ & $\bigcirc$ & $\bigcirc$ & $\bigcirc$ & $\bigcirc$ & $\bigcirc$ \\
\hline
\end{tabular}

I: Wicker work, J: Log wattle fence, K: Steel linear sodding work, L: Wattle fence with vegetation, M: Log linear sodding work, N: Linear sodding work with vegetation.

(d)

\begin{tabular}{|l|l|l|l|l|l|l|l|}
\hline$(1)$ & $(2)$ & $(3)$ & $(4)$ & $(5)$ & $(6)$ & $(8)$ & $(9)$ \\
\hline $\mathrm{O}$ & $\bigcirc$ & $\bigcirc$ & $\bigcirc$ & $\triangle$ & $\triangle$ & $\bigcirc$ & $\triangle$ \\
\hline $\mathrm{P}$ & $\bigcirc$ & $\triangle$ & $\bigcirc$ & $\bigcirc$ & $\bigcirc$ & $\triangle$ & $\triangle$ \\
\hline $\mathrm{Q}$ & $\bigcirc$ & $\bigcirc$ & $\triangle$ & $\triangle$ & $\triangle$ & $\triangle$ & $\triangle$ \\
\hline $\mathrm{R}$ & $\bigcirc$ & $\bigcirc$ & $\bigcirc$ & $\bigcirc$ & $\bigcirc$ & $\triangle$ & $\bigcirc$ \\
\hline $\mathrm{S}$ & $\bigcirc$ & $\bigcirc$ & $\bigcirc$ & $\bigcirc$ & $\bigcirc$ & $\triangle$ & $\bigcirc$ \\
\hline
\end{tabular}

O: Fagot, P: Straw mat with seed, Q: Vegetation mat with thick top soil, R: Natural fiber mat, S: Chemical fiber mat. 
Table 8: Continued.

(e)

\begin{tabular}{|l|l|l|l|l|l|l|l|}
\hline$(1)$ & $(2)$ & $(3)$ & $(4)$ & $(5)$ & $(6)$ & $(8)$ & $(9)$ \\
\hline $\mathrm{T}$ & $\bigcirc$ & $\bigcirc$ & $\bigcirc$ & $\bigcirc$ & $\bigcirc$ & $\bigcirc$ & $\bigcirc$ \\
\hline $\mathrm{U}$ & $\bigcirc$ & $\bigcirc$ & $\bigcirc$ & $\bigcirc$ & $\bigcirc$ & $\bigcirc$ & $\bigcirc$ \\
\hline $\mathrm{V}$ & $\bigcirc$ & $\bigcirc$ & $\bigcirc$ & $\bigcirc$ & $\bigcirc$ & $\bigcirc$ & $\bigcirc$ \\
\hline $\mathrm{W}$ & $\bigcirc$ & $\bigcirc$ & $\bigcirc$ & $\bigcirc$ & $\bigcirc$ & $\bigcirc$ & $\bigcirc$ \\
\hline
\end{tabular}

T: Wire net together, U: Diamond wire net, V: Thick layer wire net, W: SHIKATTO work.

(f)

\begin{tabular}{|l|l|l|l|l|l|l|l|}
\hline$(1)$ & $(2)$ & $(3)$ & $(4)$ & $(5)$ & $(6)$ & $(7)$ & $(9)$ \\
\hline I & $\bigcirc$ & $\bigcirc$ & $\bigcirc$ & $\bigcirc$ & $\bigcirc$ & $\bigcirc$ & $\bigcirc$ \\
\hline II & $\bigcirc$ & $\triangle$ & $\triangle$ & $\bigcirc$ & $\bigcirc$ & $\bigcirc$ & $\bigcirc$ \\
\hline III & $\bigcirc$ & $\bigcirc$ & $\triangle$ & $\triangle$ & $\triangle$ & $\bigcirc$ & $\times$ \\
\hline IV & $\bigcirc$ & $\bigcirc$ & $\bigcirc$ & $\bigcirc$ & $\triangle$ & $\bigcirc$ & $\bigcirc$ \\
\hline V & $\bigcirc$ & $\bigcirc$ & $\triangle$ & $\triangle$ & $\times$ & $\triangle$ & $\times$ \\
\hline
\end{tabular}

I : Steel crib structure, II : Wood crib structure, III: Cellular structure, IV: High energy absorber fence, $\mathrm{V}$ : Concrete structure.

Table 8 (f) provides an assessment of torrent work for protecting valleys that contain unstable soil. Torrent beds previously planted with Japanese horseradish have been repeatedly lost to debris flows.

Torrent works using trench soils and secondary products that are easily transported are selected for crib dams; the wood crib structure is the structure that is mainly used. The steel crib structure is best in downstream areas and at river junctions.

\section{Conclusions}

The causes of the erosion of forest lands include intense rainfall events in recent years, deforestation, and increases in wildlife numbers. The effects of global warming are increasing year-by-year: evaporation increases with a warming climate; the average global precipitation increases; soil moisture is likely to decline in many regions; and intense rainstorms are likely to increase in frequency. Deforestation within a basin causes water- and wind-derived erosion, a decline in soil fertility, and the development of landslides. It is known that the roots of Japanese red cedar and Hinoki cypress decay within 7 years of felling. It is therefore unreasonable to expect prolonged resistance to landslide development in areas of felled trees because the roots decay over time. The process of landslide development following the grazing of wild animals involves the removal of surface soil, gullying, and rill formation. The number of Japanese deer in the study area has been increasing rapidly because the area provides a 
favorable environment for the deer. The population of Japanese deer in this area has increased by $660 \%$ over the past 10 years. The rehabilitation of eroded forest land must involve both forestation measures and measures to control and manage the wildlife population at a suitable level.

The Forest Improvement Plan for the devastated area is to be carried out comprehensively via the Forestation Project and the Protected Forest Improvement Project. The Forest Improvement Plan is concerned with the growing conditions of trees, the existence of under-story vegetation, crown density, the ratio of forms, the ratio of yield, etc. The plan involves the growth of various types of under-story vegetation, the development of an ecologically multi-storied forest with sufficient ground litter, sufficient intensity of illumination under the tree crown, and enhancing the growth rate of trees by periodically carrying out forest improvement works. Such works enhance public services such as water conservation and the prevention of run-off by afforestation, and the best environment is created for wildlife.

\section{Acknowledgement}

A part of this research was conducted with the financial support of the Tokyo Metropolitan Government. The authors thank the cooperators of this survey.

\section{References}

[1] H. Iketani (1999) Disaster of Debris Flow, Iwanami Series, pp.29.

[2] Japan Forestry Society (2005) Forest Handbook, pp.9.

[3] Japan Society of Erosion Control Engineering (1999) Movable Events of Soil at Slope, Sabo Course Vol. 3, pp.169.

[4] Japan Technology Co. Ltd. (2005) General Survey Report of Forest Conservation Project in the Sakasa River, pp.1 197. 